症例

成人型 Bochdalek 孔ヘルニアの 1 治験例

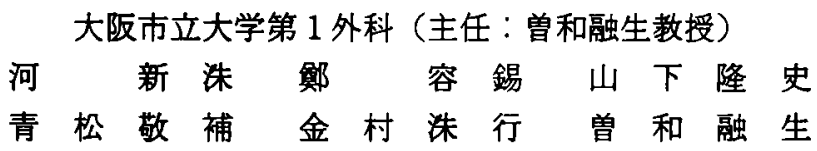

症例は45歳女性で，生来健康で学童期に異常を指摘されていない，軽度の腹痛がみら れ近医を受診し，左下肺野の異常陰影を指摘され，精查目的にて来院した，注腸造影に て結腸か脾弯曲部を先進部として，横隔膜後外側から胸腔内に入っており，成人型 Bochdalek 孔ールニフと診断された. 手術は経腹的に横隔膜裂孔閉鎖術を行い, 5 年後の現在 す異常なく経過している. 成人に発症する Bochdalek 孔へルニフは比較的まれで, 本邦 での報告例は，自験例を含め，69例がみられるにすぎない，発症年齢は男女とる20感代 に最も多く，最高は78感であった，症状は軽度の腹痛中咳敨からイレウスにいたるるの までみられた。またイレウスによりショック症状を呈したり，妊産婦では母子ともに死 亡した症例も報告されていることから，無症状であっても積㥛的に手術をすべきである と思われた。

柬引用語：Bochdalek 孔へル $=>$

\section{緒 帚}

先天性横隔膜へルニアのうち Bochdalek 孔へルニ フは新生児期に多くみられ，肺の低形成中心奇形，消 化器奇形を合併することが多く，死亡率の高い疾患と して知られている。しかし，成人に発生する Bochdalek 孔へルニアは, 小児のそれとは異なり, 症状の之 しい症例も多く，胸部単純 $\mathrm{X}$ 線写真で異常陰影を指摘 されても，胸部疾患として治療された例も少なくない。 最近, われわれは，軽度の腹痡がみられ，精查の結果， Bochdalek 孔へルニフと診断し, 根治手術を抗こなっ た比䡈的まれな症例を経験したので，文献的考察を加 え報告する。

$$
\text { 症例 }
$$

惠者：45歳，女性。

\section{主訴：左上腹部痛。}

既往歴：生下時体重は1,600g と小さかったか，生来 健康で学校検診にても異常は指摘されなかった，妊娠 歴は一度あるが流産となり，出産の経呼はない。また 特記すべき外偒の既往るなかった。

現病歴：昭和61年12月頃, 左季助部を中心に違和感 があり, 近医を受診し, 胸部 X 線撮影の結果, 肺の異

1992年 4 月 7 日受付 1992年11月18日採用
常陰影を指摘されたがそのまま放置していた。その後 異常なく経過していたが，翌年 4 月初旬以降再度同様 な症状があり，精查目的にて当科へ紹介され入院と なった。

入院時所見：身長 $137 \mathrm{~cm}$ と小さく，体重 $56 \mathrm{~kg}$ ，栄盖 状態は良好であった。聴診上心音は整で，異常雑音な く，呼吸音にも異常音を聴取しなかった。腹部は平坦 で圧痛なく，腸雑音はやや元進していた。

入院時一般検查：白血球数，赤血球数の軽度増多が みられる以外，特に異常を認めなかった（表 1).\%肺 活量 $83.5 \% ， 1$ 秒率 $81.5 \%$ ，心電図にて A 型の WPW

\section{表 1 入院時検查成紸}

\begin{tabular}{|c|c|c|c|c|c|}
\hline 一般换血 & \multirow{2}{*}{\multicolumn{2}{|c|}{$520 \times 10 \% / \mathrm{mm}^{3}$}} & 血涑ガス & \multirow{2}{*}{\multicolumn{2}{|c|}{7.369}} \\
\hline RBC & & & $\mathrm{pH}$ & & \\
\hline wBC & 10100 & $/ \mathrm{mm}^{3}$ & $P_{\mathrm{co}}$ & 34.0 & $m m H_{g}$ \\
\hline $\mathrm{Hb}$ & 17.1 & $g / d \theta$ & Po, & 74.5 & $m m \mathrm{Hg}_{g}$ \\
\hline $\mathrm{Ht}$ & 50.8 & $\%$ & BE & -4.1 & $\mathrm{mEq} / \mathrm{L}$ \\
\hline 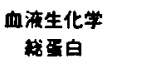 & 6.8 & $g / d e$ & 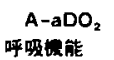 & 34.5 & $\mathrm{mmHg}_{\mathrm{g}}$ \\
\hline 战ビリルビン & 0.8 & $\mathrm{mg} / \mathrm{dl}$ & \% 肺活㗐 & 83.5 & $\%$ \\
\hline GOT & 28 & IU & 1 秒里 & 81.5 & $\%$ \\
\hline GPT & 8 & 10 & 染色体捈查 & & \\
\hline LDH & 323 & wu & 楛 型 & 46 & $x x$ \\
\hline BUN & 10 & $\mathrm{mg} / \mathrm{dl}$ & & & \\
\hline クレアチニン & 0.9 & $\mathrm{mg} / \mathrm{dl}$ & & & \\
\hline 血㴋 $\mathrm{Na}$ & 142 & $\mathrm{mEq} / \mathrm{L}$ & & & \\
\hline 血㴋 K & 4.1 & $\mathrm{mEq} / \mathrm{L}$ & & & \\
\hline
\end{tabular}


症候群を認めた。

胸部 X 線単純撮影：立位にて左横隔膜に不正陰影 がみられた(図 1 左)。臥位胸部単純撮影にて，胸部へ
の異常がス像の増強がみられた（図 1 右）.

注腸造影：横行結腸から下行結腸に当たる結腸は脾 弯曲部完先進部として左横隔膜後外側より胸腔内に陷
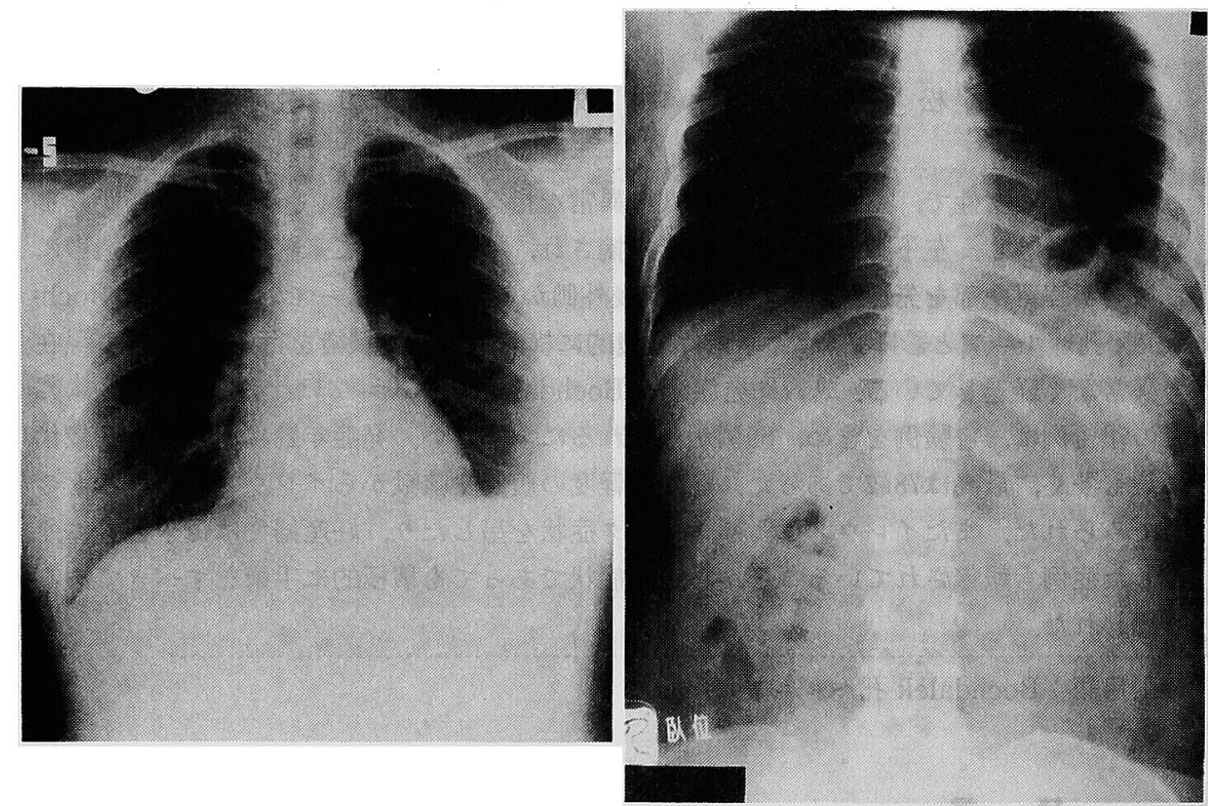

図 1 胸部腹部単純撮影：左；立位胸部単純撮影正面像にて左下肺野横隔膜の不正陰 影がみられた。右：腹部単純撮影臥位像にて胸腔内へ腸管がス像の脱出がみられる。
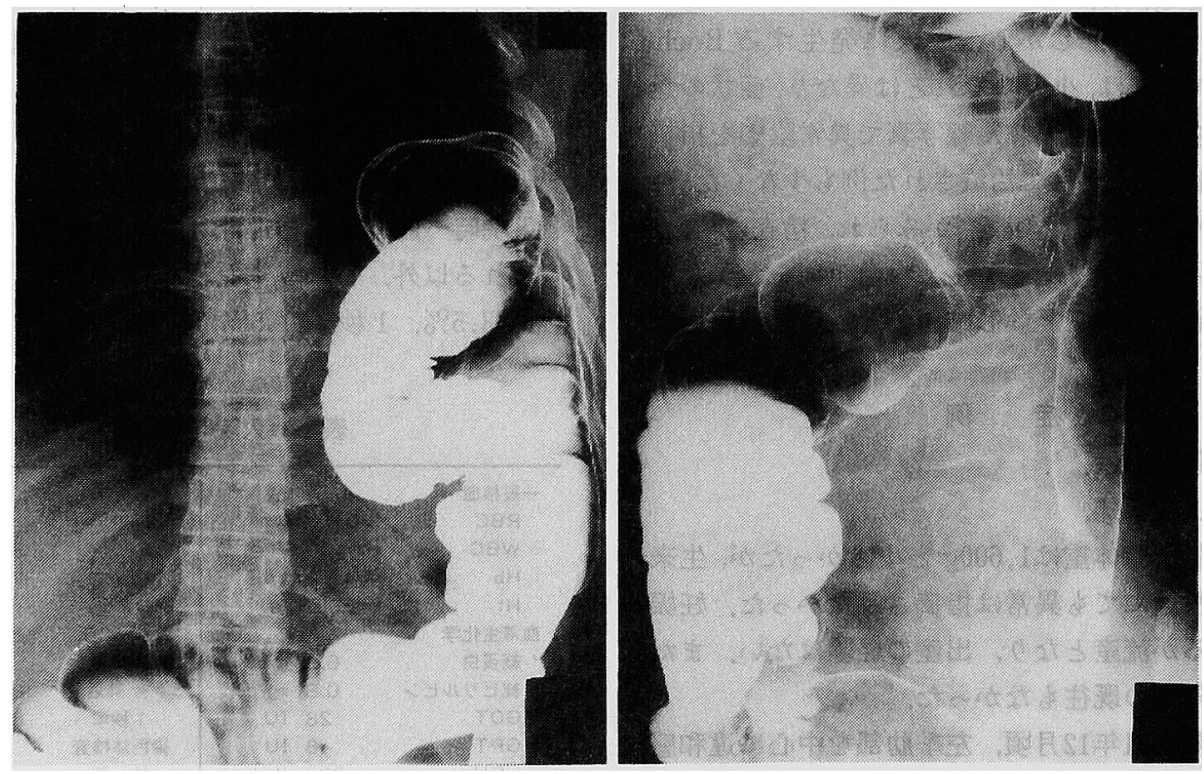

図 2 注腸造影：左；胸腔内に横行結腸から下行結腸にかけ左結腸曲を中心に胸腔内 への脱出がみられた，右；盲腸から上行結腸は後腹膜に固定されておらず，側面像 で前方への変位がみられ，総腸間膜症の合併が疑われた。 
入しており，回盲部と上行結腸は上内側に，側面像で は回盲部が腹側に変位し総腸間膜症の合併が疑われた

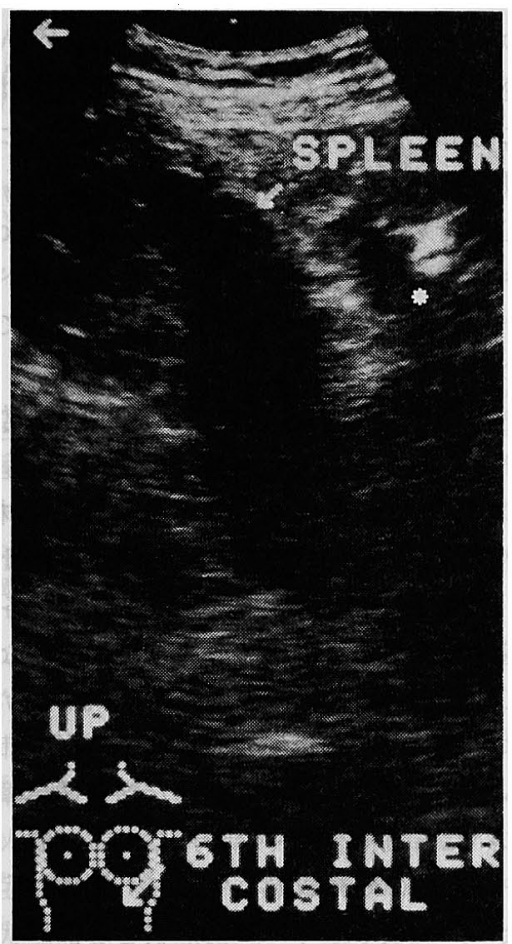

図 3 胸腹部超音波検查: 左第 6 助間操作にて脾藏

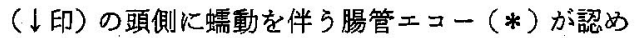
られた。
(図 2 左, 右).

腹部超音波検査：左側胸部第 6 肋間操作にて脾臓が 描出され，横隔膜下に位置していたが，その頭側に蠕 動を伴ら腸管エコー像がみられた（図３）.

胸腹部 CT 検査：左下部胸腔内に腸管像が認められ た（図4)。

な技上部消化管透視では異常所見を認めなかった。

以上の所見より総腸間膜症を伴った Bochdalek 孔 ヘルニアと診断し手術を施行した。

手術所見：左上傍腹直筋切開にて開腹，横行結腸に 相当寸る結腸は左横隔膜後外側の横隔膜欠損部（へル ニア門)より胸腔内に陷入し，それより口側の上行結 腸から回盲部にかけての結腸は著明に拡張していた。

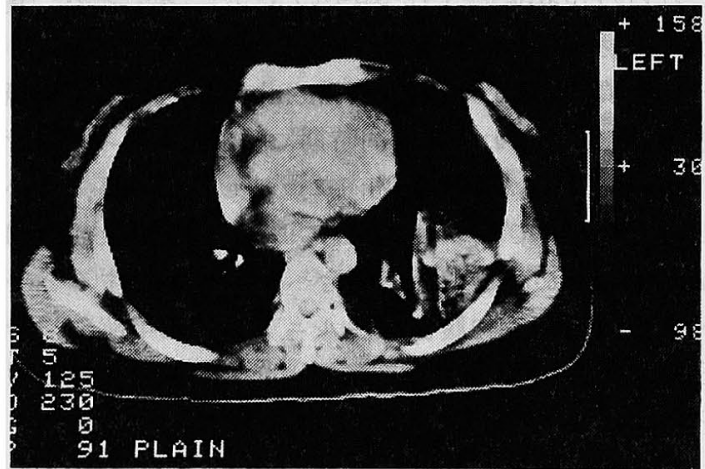

図 4 胸部 CT 検查：左側胸腔内で背側より（横隔膜 直上）に腫瘤像がみられた。

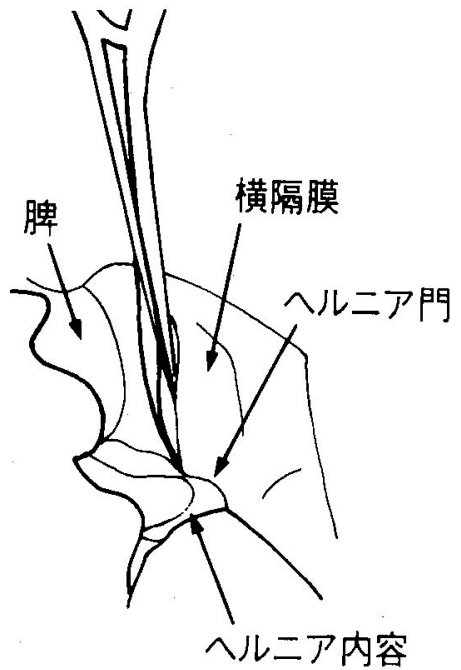

図 5 手術所見：左胸腹裂孔より結腸の胸腔内への脱出がみられた。へルニア門の大 きさは $7 \times 4 \mathrm{~cm}$ でヘルニア覆は認められなかった。 
腸管は十二指腸と $\mathrm{S}$ 字状結腸の一部で後腹膜に固定 されていたか，小腸間膜と結腸間膜との区別はなく， 総腸間膜症の合併がみられた。、ルニフ門は約 $7 \times 4 \mathrm{~cm}$ で、ヘルニア門と結腸間膜の間に一部撚着がみられた。 瘾着を剥離し脱出した結腸を腹腔側へもどしたとこ ろ、ヘルニア門より直接肺が観察され、ヘルニア蓄は みられなかった。、ルニフ門は張力がかかることなく， 二層に縫合閉鎖することができ，胸腔内に持続吸引ド レーンを㨂入し手術を終了した（図 5).

術後経過: 肺の払張は良好で, 術後 3 週間後に軽快 退院し，5年経過した現在も異常なく経過している.

\section{考 察}

発生学上, 横隔膜は 5 つの hiatus に分けられ, 胎生 8 週頃になると次第に瘏合し，一つの膜状構造となる。 これらの hiatusの5ち, 中央の 3 つは, それぞれ，食 道, 大動脈，大静脈の裂孔を成し，残る 2 つは胎生 8 〜10週頃に pleuroperitneal membrane となって閉鎖 する(図 6)。これとほぼ同時期に㨊帯内にあった腸管 は270度回転しながら腹腔内に還納しはじめる。しか し、その途中で何らかの原因により, pleuroperitneal membrane が閉鎖しない場合へルニフが生ずるとい われる。功る胸腹裂孔ールニアは1848年解剖学者 Bochdalek ${ }^{1}$ か， 新生児剖娭例よりその発生病理を明 らかにしている.

新生児や幼児に発生した Bochdalek 孔へルニアの 場合, 分婏時に異常がなければ先天性であることは明 らかであるが，成人の場合，症状の発現にいたるまで に多くの外的因子が関与することが考えられる。とく に女性では妊娠後期に発見された横隔膜へルニフの一 部には，腹圧上昇に伴ら外傷性へルニアが含まれてい るとする報告むみられる。このように外傷性と先天性 との鑑別は困難なこともあるが, 明らかな外傷の既往 のない場合，一般に先天性とする報告が多(、8)912)15)。

16歳以上の成人に発生した Bochdalek 孔ール の報告は，文献上，欧米では Thoma $(1882)^{22}$ か，本邦

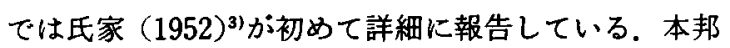
ではこれまでに自験例を含め69例の報告がみられる。 年齢は16歳から78歳までみられ, 平均は35.8歳, 男女 ともそれぞれ20歳代にピークがみられた。男女比は

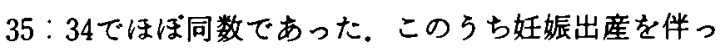
ていた症例は12例で，20歳代の女性が10例(67)11133) と多 く, 妊娠による腹王の上昇か herniation を増強し, 発 症に至るもの゙と考えられる。

ヘルニフの発生部位の記載のある60例についてみる

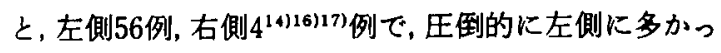
た。右側には肝葴があり，また発生学上，横隔膜は右 側より左側の pleuroperitneal canal の閉鎖が遅れる ためとされている9)。ヘルニて震は記載のある46例中 1 例"1)のみで、一ルニフ整を伴わない症例が多く，自験 例でも認められなかった。ヘルニフ衰の有無は議論の あるところで, ドイッでは, ヘルニフ整をむつものを Bochdalek 孔へルニアとされ，報告例は少ないか，本 邦をはじめその他の国では無雍の症例むBochdalek 孔へルニフとしてあつかわれ゙,トトイッに此べその報 告は多い．また新生児や小児に比べ5)，成人型では極端 に無萲の症例が多いよらである。

合併奇形は総腸間膜症ならびに腸回転異常症か12 例早9)13222) と最も多く, その他に心葴奇形 (心室中隔欠 損症"1, 右側大動脈弓 ${ }^{211}$ ), 骨軟部組織奇形(胸椎異常, 過剩胸腔内助骨) 2 例, 完全内䐵転位症, high renal ectopia', Morgagni 孔ール ${ }^{51}>^{17}$ の合併が各 1 例み られ，腸回転異常の合併が多い上らである。な拉，自 験例のごとくWPW 症候群の合併例はなかった。

症状は小児，とくに新生児では心臓奇形や肺の低形 成を伴っていることが多く，重篤な呼吸循環障害をき たし死にいたる例む少なくない，しかし，成人例では 呼吸器や循環器は既に成熟しており，重篤な症例は比 較的少ない，症状の多くは胸部症状と腹部症状とに分 けられ, 胸部症状としては, 胸痛 8 例, 呼吸困難 9 例, 喘息様症状 3 例などで，そのうち自然気胸を合併した 1 例26)を除き，いずれも軽症であった. 腹部症状は腹痛 が25例と最も多かったが，他にイレウス症状（胃軸捻 転症を含む） 7 (例1423) 25)27), 腹部不快感 3 例と軽症例 から重症例までみられた。

診断は，既往に肺野の異常を指摘された症例が比較 的多いが, costphrenic angle や横隔膜陰影に軽度の異 常がられるのみで, 胸部 X 線上では診断が困難な例 る少なくない，このような場合，多くは臨床症状に乏 しく見落とされがちたか，体位变換による撮影，長時 間臥位をとった後の撮影，腹部圧迫による撮影なとに より，胸部単純 X 線撮影で胸部に限局した異常陰影の 増強や脱出腸管のガス像などがみられることがあり， 診断に役立つものと考えられる。自験例でも，立位よ り臥位で明らかに胸腔内への腸管の脱出の増強がら れた。

ヘルニア内容は結腸 46 例, 小腸 31 例, 脾臓29例，胃 28例, 大網・腸間膜27例, 腎葴 4 例(5)820), 膵缄9113) と肝

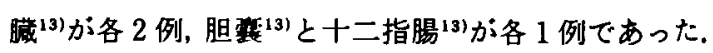




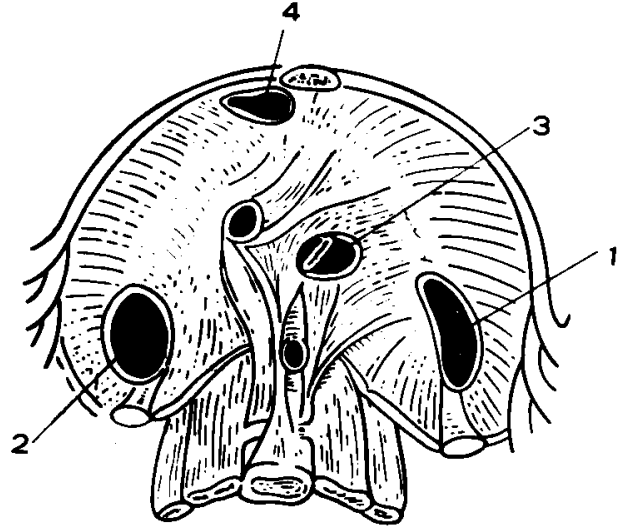

图 6 獚隔䐜へルニアの裂孔位置: 1. PosteroLateraler Defekt (Bochdalek). 2. DorsoLateraler Defekt (Hiatus pleuroperitonealis). 3. Erweiterung d. Hiatus Oesophagicus. 4. Hernia Parasternalis. (r: Morgagni 孔, 11 : Larrey 孔)

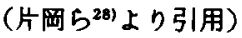

このよらにヘルニア内容に結腸，小腸，脾䁍，胃なぞ が多いことより，注腸透視ならびに上部消化管透視が 最も重要と思われた。，小児，とくに新生児では，注腸 透視ならびに上部消化管透視は比較的禁忌とされてい るが，成人では問題はないと思われる。しかし，イレ ウスを呈している場合は腸管の嵌頓壊死が疑われる場 合もあり注意を要する。また大網・腸間膜のみの場合， 超音波検查や CT あ有用と思われる ${ }^{21}$.

鑑別診断として, 外傷性横隔膜ヘルニフ, 横隔膜地 緩症があるが，明らかな外傷の既往がある症例以外， 術前の鑑別は困難なことも多い。また Morgagni 孔一 ルニフとの鑑別は図 6 のごとくへルニてれの位置が異 なり，前後像にて容易に鑑別できると思われる28．

発症様式は，記載の明らかな55例中，急性発症型 24 例, 亜急性型12例, 慢性型17例，無症状 6 例5120177)-19)で あった，急性発症24例のうち妊娠を合併していたもの が 9 例みられ，いずれる妊娠 5 力月以降に発症してお $\eta$ ，急性発症例の $37.5 \%$ 占めていた。この内の 1 例 は母子とも死亡している。䍃性イレウス症状を 呈し，来院時すでにショック状態であった 3 例に死亡 がみられている。このように急性発症例で死亡例が計 6 例報告されていることから，注意深い観察を必要と し，妊娠後期に発見された場合は帝王切開も考虑する 必要がある。また男性あるいは妊娠と無関係な女性で も，可能なかぎり積極的に手術すべきであると思われ る.
手術経路は，記載のある52例中，経胸法23例 (44\%)， 経腹法23例 (44\%)，経胸経腹法 6 例 (12\%) で，経胸 例と経腹例がほぼ同じであった，経胸法，経腹法のい

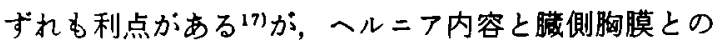
瘄着がみられた症例は 1 例のみで，経腹法で手術が可 能である症例が多いよ5である，われわれの症例む経 腹操作のみで，嵌入腸管を腹腔側に還納することがで きた，妊娠合併例や高齢者では，経腹法が有利と思わ れるが，自然気胸を合併していた症例では経胸操作に より行われており，症例に応して経胸または経腹操作 のいずれかを選択すべきすのと思われる。なお，へル 二フ門に関しては，記載のある34例の内，最小は $2 \mathrm{~cm} \times$ $2 \mathrm{~cm}$, 最大 $15 \mathrm{~cm} \times 10 \mathrm{~cm}^{23)}$, 平均 $7.5 \mathrm{~cm} \times 5.4 \mathrm{~cm}$ で, 自 験例は $7 \mathrm{~cm} \times 4 \mathrm{~cm}$ であった。多くは横隔膜を二層に繾 合する直接艇合が可能であるか，閉鎖困難な症例では Ivalon nylon sponge mesh, 最近では Marlex mesh などで補強が行われている211.

\section{結語}

45年間ほぼ無症状で経過し，釉腸管膜間を合併した Bochdalek 孔へルニアの 1 例を経験したので, 成人型 Bochdalek 孔へルニアの本邦での文献的集計を行い 報告した。

本症例の要旨は第396回大阪外科集談会で発表した。

$$
\text { 文献 }
$$

1) Bochdalek VA: Einige Betrachtungen über die Entstehung des angebornen Zwerchfellbruches. Vierteljahrschr f d prak Heilk (Prag) $19: 89-97,1848$

2) Thoma R: 4 Fălle von Hernia diaphragmatica congenita. Virchows Archiv Bd $38: 515$ $-519,1882$

3）氏家 基, 江本俊秀, 野沢直道他：横隔膜ヘル $=7$ の 2 例（特に気虫内麻醉による手街治験），外科 $14: 104-106,1952$

4）宮本 忍, 瀬在幸安, 佐藤 規地：Bochdalek 氏 横隔獏へルニフの1治験例，胸外 $14: 909-915$, 1961

5）依田亘正, 竹田采一, 長久保一朗：High renal ectopia 合併せる先天性 Bochdalek 氏孔へルニ フの 1 例, 日胸臨 $30: 913-918,1971$

6）勝呂 長, 林裕人, 藤原羲剛他：成人にみられた Bochdalek 孔ールニフの1治稅例。胃と腸 $7: 69$ $-74,1972$

7）中沢康夫, 福田義人, 山川 真他：妊娠末期に発生 した Bochdalek 孔へルニフの1 例, 南大阪病医誌 
$20: 51-54,1972$

8）桑原能雄, 田中基樹, 岩崎有良他：先天性横隔膜一 ルニフの1例，治㞠 $55: 155-158,1973$

9）遠藤 篤、睠見正治，梁 贵容他：成人にみられた ボホダレック孔へルニアの 2 症例、日臨外医会誌 $34: 158-164,1973$

10）川井田繁，小田原良治，野村秀洋他：42年間無症状 に経過した Bochdalek 孔ヘルニフの1治験例，外 科 $38: 863-865,1976$

11）高知床志, 岡崎裕行, 富山吉久他：妊娠 7 力月経産 婦に発生した Bochdalek 孔へルニフの 1 症例, 産 と婦 $45: 99-102,1978$

12）佐藤太一郎, 七野淡彦, 早川直和他：成人 Bochdalek 孔へル $=ア の 1$ 例, 外科 39 ：938-942, 1977

13）三好新一郎，門田康正，中原数也他：成人 Bochdalek 孔ヘル $=7 ー 3$ 治検例と本邦報告58例の検 討, 日胸外会誌 $31: 103-109,1983$

14）越智祥隆，本郷三郎，渡部高昌他：胃軸捻転症を合 併した成人右 Bochdalek 孔へルニアの 1 治検例, 臨外 39:139-142, 1984

15）西田正之，細井睦美，田中茂樹他：自衛官にみられ た成人ボクダレックールニ7の 2 治呤例，防衛医 大誌 $10: 105-109,1985$

16）財間正純, 浦辺千晶, 合桥卓男他：成人 Bochdalek 孔へルンフの 1 手術治検例, 外科 $46: 753-756$, 1984

17）小野誠治, 杜若陽祐, 星 博昭他: Morgagni 孔一 ルニフと Bochdalek れへルニフの合併症一CT 所見を中心として，臨外 $30: 509-512,1985$

18）国延浩史，佐伯俊昭，大屋正章他：成人 Bochdalek
孔ヘルニフの1治稄例，広島医 $39 ： 559-562$, 1986

19）浜田弘巳，澤谷令兒，黒田健司他：無症状で発見さ れた成人 Bochdalek 孔ールニフの 1 治㰸例, 北海 道外科誌 $32: 58-61,1987$

20）本多正治, 大川 淳, 粐山卓哉他：成人 Bochdalek 孔へル =フの1例，厚生年金病年報 $14: 67-72$, 1987

21）中村 優, 国田哲子，島本丈裕他：右側大動脈弓を 伴った成人 Bochdalek 孔ヘルニフの1 例, 㕕島医 $41: 84-87,1988$

22）遠山信幸, 黒沢知徳: 成人 Bochdalek 孔へル $=7$ の 1 治験例，埼玉県外医誌 $22: 756-758,1989$

23）高浪藉, 師田 昂, 四方淳一：成人にみられた胃 軸捻転䟚を伴 5 Bochdalek 孔へルニフの 1 例, 日 胸外会誌 $38: 1488-1491,1990$

24）八反田洋一, 朔 元則, 秀島煇他：胃軸捻転症を 併発した成人横隔膜へルニ7（Bochdalek Hernia）の1例，日臨外医会誌 $45: 762-766,1984$

25）徱屋和雄, 小山 勇, 山崎達雄他：成人 Bochdalek 孔ールニアによる胃軸捻転应の 1 症例，腹部救急 診療の進歩 $7: 901-905,1987$

26）奥村明之進, 安光 勉, 古武黹宏他：自然気胸を合 併した成人 Bochdalek 孔ヘルニフの 1 治検例，日 呼外会誌 $5: 79-85,1991$

27）廣海洋三，森田 茂。岛田隆男他：低カリウム血症 の心䉓図異常を認めた胃短軸淰転症を伴った横隔 膜へルニフの1例，呼吸と循環 39：715-719， 1991

28）片岡一朗, 蟹江弘之, 桜井峈彦他：横隔膜へル = について，臨外 22:51-60, 1967

\section{A CASE OF ADULT BOCHDALECH HERNIA}

\section{Sin-Soo HA, Yong-Suk CHUNG, Takashi YAMASHITA, Keiho AOMATSU, Mizuyuki KANEMURA and Micho SOWA}

First Department of Surgery. Osaka City University Medical School (Director: Prof. Michio SOWA)

A case of adult Bochdalech hernia in a naturally healthy 45 -year-old woman is reported. The patient was seen at the hospital for further examination, because she was indicated as having an abnormal shadow in the left lower lung field after consulting a nearby doctor for a slight abdominal pain. Barium enema revealed a dislocation of the colon into the thorax through the left posterior-lateral diaphragma and adult Bochdalech hernia was indicated. The resection method used for the postero-lateral diaphragma defect was done via the abdominal cavity, resulting in a 5-year trouble-free period. Adult Bochdalech hernia is relatively rare, and only 69 case sincluding this case have been reported in the Japanese literature. Most cases involved persons in their twenties and the oldest was a 76-year-old person. The most common symptom included a slight abdominal pain, cough, or ileus. Since some cases affected by ileus driven shock, and mother and child died together due to herniation were reported, radical operation should be recommended when asymptomatic. 